\title{
Effect of hexavalent carcinogenic chromium on carp Cyprinus carpio immune cells
}

\author{
Dieter Steinhagen $^{1, *}$, Tobias Helmus ${ }^{1}$, Stephan Maurer ${ }^{1}$, R. Dinakaran Michael ${ }^{3}$, \\ Wolfgang Leibold ${ }^{2}$, Jörn P. Scharsack ${ }^{1}$, Andreas Skouras ${ }^{1}{ }^{1}$ Hans-Joachim Schuberth ${ }^{2}$
}

\author{
${ }^{1}$ Fish Disease Research Unit, ${ }^{2}$ Immunology Unit, Hannover School of Veterinary Medicine, Bünteweg 17, 30559 Hannover, \\ Germany \\ ${ }^{3}$ Centre for Fish Immunology, Postgraduate and Research Department of Zoology, Lady Doak College, Madurai \\ Tamil Nadu, India
}

\begin{abstract}
Chromium is widely used in industrial processes, and is released into aquatic environments by electroplating, tannery and textile industries. Fishes in natural waters or in aquaculture facilities supplied with these waters are exposed to chromium waste and are presumed to be affected by deposits. Herein, we examine the effect of hexavalent chromium on carp Cyprinus carpio derived immune cells. In vitro exposure of carp leukocytes to hexavalent chromium induced cytotoxicity, decreased mitogen-induced lymphocyte activation and phagocyte functions at concentrations between 2 and $200 \mu \mathrm{mol} \mathrm{Cr} \mathrm{l}^{-1}$. Neutrophils responded to chromium challenge by changes in cell shape together with reduced nitric oxide and reactive oxygen production. This occurred at much lower concentrations than for the cytotoxic effects seen in leukocyte cultures derived from peripheral blood or pronephros. In a similar way, activation of carp lymphocytes by pokeweed mitogen was reduced in a dose-dependent manner, while cytotoxic effects on non-activated lymphocytes were observed at much higher doses of $200 \mu \mathrm{mol} \mathrm{Cr}{ }^{-1}$. Altered lymphocyte and neutrophil functions are considered to be responsible for decreased resistance to pathogens observed in fishes under chronic chromium challenge.
\end{abstract}

KEY WORDS: Heavy metal · Hexavalent chromium · Cytotoxity · Immunomodulation

\section{INTRODUCTION}

Chromium is a widely used substance in various industrial processes, such as the production of stainless steel, manufacture of pigments or dyes, and the preservation of wood. These processes release chromium into the environment and expose man and animals to deposits in soil and water. Electroplating operations, leather-tanning and the textile industry have been identified as major anthropogenic sources for the deposition of chromium in freshwater environments (ATSDR 2000). The chemical form or speciation of a metal is an important factor in determining its absorption and biological effects. There are 6 valence states of chromium, but only $\mathrm{Cr}$ (III) and $\mathrm{Cr}(\mathrm{VI})$ are widely distributed and play a significant role in toxicology. Valency widely determines the ability to penetrate skin or biological membranes (ATSDR 2000). Chromium (VI) readily penetrates skin and cell membranes, is quickly reduced by intracellular proteins to $\mathrm{Cr}$ (III) and forms complexes with haemoglobin or sulphhydrylcarrying amino acids in proteins (Langård 1982). Chromium (III) is a very reactive cation, and readily binds with proteins, which effectively prevents its entrance into the blood stream (for review see Polak 1983, Arfstein et al. 1998). It serves as a co-factor for insulin action and is an essential element in mammalian nutrition (Goyer 1991, Vincent 1999). The biological active form of $\mathrm{Cr}$ (III) is sometimes referred to as the 'glucose tolerance factor'. $\mathrm{Cr}(\mathrm{VI})$ is highly toxic, carcinogenic and may cause DNA damage such as DNA-strand breaks. Its toxicity is considered to be related to a generation of reactive oxygen species as a result of cellular reduction of $\mathrm{Cr}(\mathrm{VI})$ to $\mathrm{Cr}(\mathrm{V} / \mathrm{IV} / \mathrm{III})$ 
(Ye et al. 1999). Alpoim et al. (1995) reported that $\mathrm{Cr}$ (VI) reduced intracellular glutathione levels, which further supports the hypothesis that $\mathrm{Cr}(\mathrm{VI})$ may cause toxicity by inducing oxidative stress that results in oxidative deterioration of biological macromolecules (Stohs et al. 2000).

Immunotoxicity data for chromium are sparse and inconsistent, but indicate that chromium exposure may cause immunosuppression (for review see Arfstein et al. 1998). In fishes, the exposure of the freshwater catfish Saccobranchus fossilis to subtoxic level of $\mathrm{Cr}$ resulted in decreased antibody production, reduced proliferation of splenic lymphocytes, and higher susceptibility to infections with the microorganism Aeromonas hydrophila (Khangarot et al. 1999). Exposure of the freshwater cichlid Oreochromis mossambicus to chrome tannery effluents (Sudhan \& Michael 1995) or the injection of chromium compounds into the body cavity (Arunkumar et al. 2000) resulted in spleen atrophy, decreased leukocyte counts and antibody response upon the injection of bovine serum albumin.

Few studies have evaluated the effect of chromium on immune cells and immune functions in vitro. Chromium (VI) irreversibly inhibited DNA synthesis to $50 \%$ in a mouse cell line (Nishio \& Uyeki 1985), suppressed mitogen-induced human lymphocyte proliferation (Borella \& Bargellini 1993) and modulated the nitric oxide production of murine macrophages (Tian \& Lawrence 1996).

Based on the widespread use of chromium in industry and the prevalence of chromium contamination in aquatic habitats, there is a need for immunotoxicological data for chromium in order to assess health risks for aquatic animals associated with this metal. In this communication, we report the effects of chromium on piscine immune cells in vitro.

\section{MATERIALS AND METHODS}

Fish. Carp from a single crossing $($ E20 $\times$ R8, Wageningen Agricultural University, The Netherlands) were used throughout the study. The female (E20) originated from an outbred female which was propagated gynogenitically. This isogenic female was propagated with an outbred male (Wiegertjes et al. 1995). The carp were propagated and raised in the laboratory in filtered recirculated tap water under pathogen-free conditions at 20 to $23^{\circ} \mathrm{C}$. For blood and organ collection, 12 to 18 mo-old carp of 150 to $200 \mathrm{~g}$ were used.

Culture media. Media for isolation and cultivation of carp leukocytes were adjusted to carp blood osmolarity by the addition of $10 \%$ [v/v] double-distilled water. For blood collection, diluted RPMI 1640 medium (Bio- chrom) was supplemented with $100000 \mathrm{IU} \mathrm{l}^{-1}$ sodium heparin (Sigma; heparinised medium). For washing procedures, diluted RPMI was supplemented with $10000 \mathrm{IU} \mathrm{l}^{-1}$ sodium heparin (wash medium). For cell cultivation, $3 \% \quad[\mathrm{v} / \mathrm{v}]$ of pooled, heat-inactivated $\left(30 \mathrm{~min}, 52^{\circ} \mathrm{C}\right.$ ) carp serum was added to diluted RPMI (culture medium). In addition, the culture medium was supplemented with $100000 \mathrm{IU} \mathrm{l}^{-1}$ penicillin, $100 \mathrm{mg} \mathrm{l}^{-1}$ streptomycin and $4 \mathrm{mmol} \mathrm{l}^{-1}$ L-glutamine (all chemicals: Biochrom).

Leukocyte isolation. Fish were anaesthetised by immersion in $0.15 \mathrm{~g} \mathrm{l}^{-1}$ tricaine methane sulphonate, and blood was drawn from the caudal blood vessel into a syringe prefilled with heparinised medium. Leukocytes were isolated from erythrocytes by centrifugation (30 $\mathrm{min}, 755 \times g$ ) over Lymphoprep (Nycomed) as described by Miller \& McKinney (1994). Cell suspensions from the head kidney were made by forcing the tissue through a $100 \mu \mathrm{m}$ nylon screen (Swiss Silk Bolting Cloth Mfg). Peripheral blood (PBL) and head kidney leukocytes (HKL) were washed 3 times with wash medium $(10 \mathrm{~min}, 550 \times g)$ and re-suspended in cell-culture medium. Numbers of viable cells were enumerated in a cell-counting chamber. Viability of cells, as monitored by means of a Trypan blue exclusion assay, in all preparations was above $95 \%$. In HKL cell suspensions, the erythrocyte contamination was not more than 5 to $7 \%$. Media and cells were kept on ice throughout the isolation procedure and centrifugation steps were performed at $4^{\circ} \mathrm{C}$.

Leukocyte culture. For cultivation experiments, cells were inoculated into flat-bottomed microtiter plates (96 wells) at a density of $10^{6}$ cell well $^{-1}$ in a final volume of $175 \mu \mathrm{l}$ culture medium. Hexavalent chromium was added as potassium dichromate solution (Merck Darmstadt) at final concentrations of 2, 20, 200 and $2000 \mu \mathrm{mol} \mathrm{l}^{-1}$. Mitogen stimulation of PBL was brought about by the addition of pokeweed mitogen (PWM, $1 \mathrm{mg}^{-1}$ ). All experiments were made with cells from at least 4 individuals; the cells from each individual were used in triplicate. Cells were incubated in a watervapour-saturated atmosphere with $3 \% \mathrm{CO}_{2}$ at $27^{\circ} \mathrm{C}$ for 2 to $6 \mathrm{~d}$.

Production of reactive oxygen species. Head kidney leukocytes $\left(1 \times 10^{6}\right.$ well $\left.^{-1}\right)$ were incubated with or without phorbol myristate acetate (PMA, $15 \mathrm{mg} \mathrm{l}^{-1}$ ) in the presence of nitroblue tetrazolium (NBT, $1 \mathrm{~g} \mathrm{l}^{-1}$ ) for $2 \mathrm{~h}$ at $22^{\circ} \mathrm{C}$. Then, after removing the supernatants, the cells were fixed with methanol for $5 \mathrm{~min}$, and air-dried after 2 washes with $70 \%$ [v/v] methanol. Reduced NBT was dissolved in $125 \mu \mathrm{l} 2 \mathrm{M} \mathrm{KOH}$ and $125 \mu \mathrm{l}$ DMSO (all chemicals from Sigma) and the optical density was recorded with a spectrophotometer at $650 \mathrm{~nm}$.

Nitric oxide secretion. The secretion of nitric oxide by HKL was measured by means of the Griess reaction 
according to standard procedures. The Griess reagent indicates the presence of nitrite as a surrogate for the short-lived NO (Green et al. 1982). The supernatant was collected from HKL cultures incubated with PWM for $4 \mathrm{~d}$, and $50 \mu \mathrm{l}$ were transferred to a separate microtitre plate and mixed with $50 \mu \mathrm{l}$ of Griess reagent. The optical density was recorded with a spectrophotometer at $570 \mathrm{~nm}$ after a reaction time of $10 \mathrm{~min}$. Molar concentrations of $\mathrm{NO}_{2}^{-}$were calculated from a standard curve generated from a graded series of $\mathrm{NaNO}_{2}$ concentrations in culture medium.

Flow cytometric analysis. Suspensions of head kidney as well as peripheral blood leukocytes were analysed by means of a flow cytometer (FACScan ${ }^{\circledR}$, Becton Dickinson, single excitation wavelength of $488 \mathrm{~nm}$ ). Forward-scatter (FSC) and side-scatter (SSC) characteristics of at least 10000 cells per sample were acquired in a linear mode, and fluorescence intensities at 530 and $650 \mathrm{~nm}$ were recorded in a logarithmic mode. Differential cellular subsets were identified according to their characteristic FSC/SSC pattern (Verburg-van Kemenade et al. 1994, Scharsack et al. 2003), which was backed by morphological observations.

Total numbers of cells were recorded by means of the standard cell-dilution assay (Pechhold et al. 1994). Culture plates were placed on ice for $10 \mathrm{~min}$, shaken, and the whole content of each well was transferred to individual flow cytometer tubes. Standard cells $\left(2 \times 10^{5}\right)$ and $2 \mathrm{mg} \mathrm{l}^{-1}$ propidium iodide (Calbiochem) were added to each tube. Standard cells were formaldehydefixed, fluorescein isothiocyanate (FITC)-labelled, bovine mononuclear cells (Schuberth et al. 1992). They were used to quantify non-labelled HKL or PBL. After acquisition of at least 10000 events, the data were analysed by means of WinMDI 2.8 software package (Trotter 1998; available at http://www.facs.scripps.edu/ software.html). Cellular debris with low FCS characteristics and propidium iodide-positive, dead cells were excluded from further evaluation. Standard cells (propidium iodide ${ }^{+v e}$, FITC $^{+v e}$ ) were discriminated from viable cells (propidium iodide ${ }^{-v e}$, FITC $^{-v e}$ ), and the total numbers of viable cells in individual wells were calculated as number of viable cells $=$ events of viable cells $\times$ number of standard cells/events of standard cells.

Statistics. To determine the significance of differences between groups, data were compared by a Kruskal-Wallis ANOVA and a subsequent multiple comparison by means of the Student-Newman-Keuls method at a probability error of $\mathrm{p}<0.05$.

\section{RESULTS}

\section{Cytotoxicity}

In vitro chromate had a cytotoxic effect on carp immune cells at concentrations above $2 \mu \mathrm{mol} \mathrm{l}^{-1}$. When peripheral blood or head kidney-derived leukocytes were cultivated in the presence of 20 or $200 \mu \mathrm{mol} \mathrm{l^{-1 }}$ chromate (Fig. 1a) or were incubated in culture media supplemented with 20 or $200 \mu \mathrm{mol} \mathrm{l}^{-1}$ chromate for $18 \mathrm{~h}$, a decrease in cell numbers relative to control cultures was seen in a dose-dependent manner. To investigate whether serum proteins or antioxidants play a role in the protection of cells against cytotoxic effects of chromate, we added alpha tocopherol (Vitamin E) and in- a

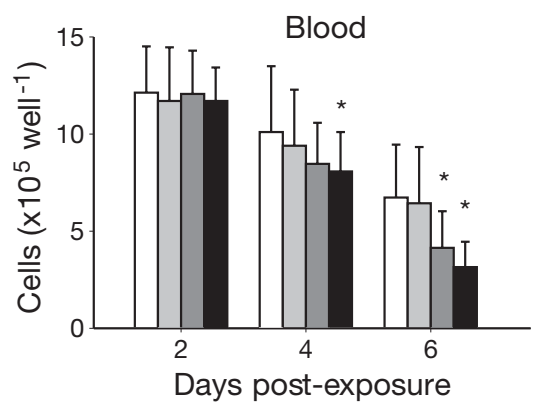

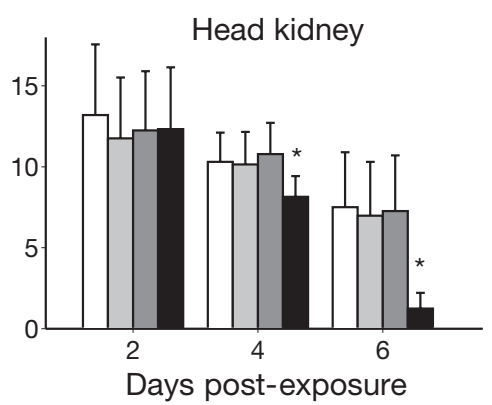

Days post-exposure b

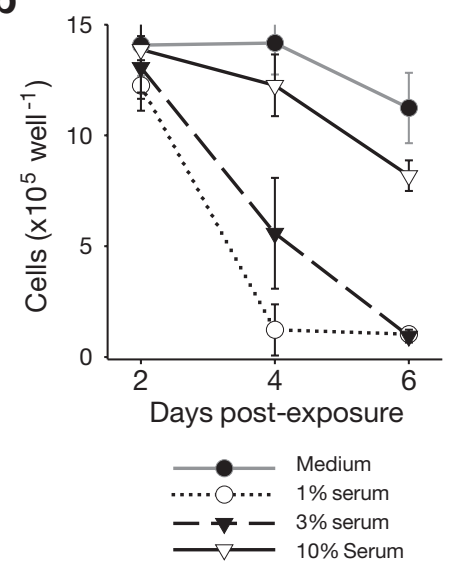

Fig. 1. Cyprinus carpio. (a) Impact of hexavalent chromium on viability of peripheral blood and head kidney-derived leukocytes; leukocytes were incubated in presence of chromium at $25^{\circ} \mathrm{C}$. (b) Modulation of chromium-induced cytotoxicity for carp leukocytes by serum supplementation of culture medium. Head kidney-derived carp leukocytes were incubated in culture medium

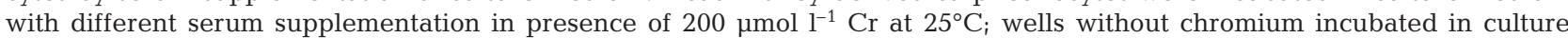
medium without serum served as controls. After 2, 4, or $6 \mathrm{~d}$, total cell numbers were determined by means of flow cytometry (means and standard deviations of cultures from 6 [blood] or 9 [head kidney] individual carp). Significant differences (indicated

by *) relative to control at $\mathrm{p}<0.05$ were detected in all cultures supplemented with chromium after 4 and $6 \mathrm{~d}$ incubation 

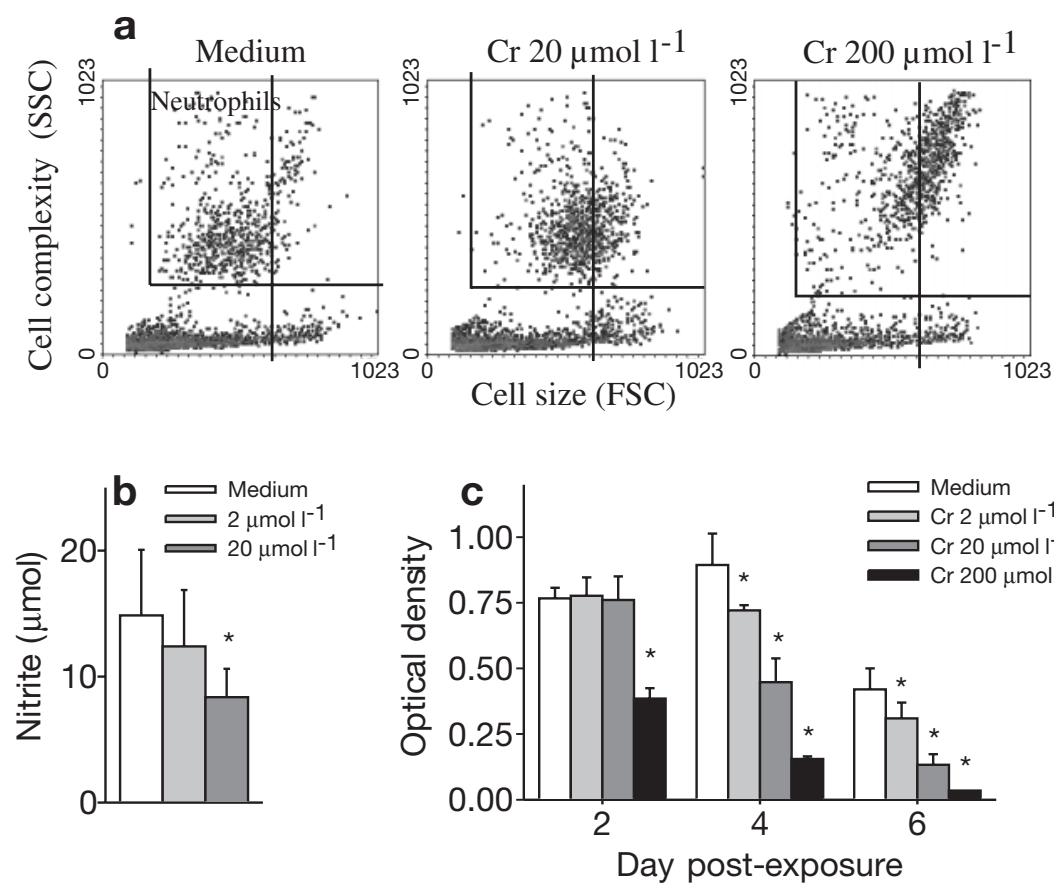

Fig. 2. Cyprinus carpio. Impact of hexavalent chromium on head kidney leukocytes. (a) Flow cytometric characteristics of head kidney leukocytes of carp after $2 \mathrm{~d}$ incubation in culture medium (Medium), 20, or $200 \mu \mathrm{mol} \mathrm{l} \mathrm{l}^{-1}$ chromium; cells were incubated at $25^{\circ} \mathrm{C}$. Shown are forward-scatter (FSC) versus side-scatter (SSC) density diagrams of cells from 1 of 9 carp analysed; neutrophils appear in upper right panel of graphs. In control cultures, majority of neutrophils had FSC characteristics smaller than the vertical bar on the right of each graph. In chromium-exposed cultures, scatter characteristics showed increased values. Cells from the 9 carp examined gave identical results. (b) Impact of hexavalent chromium on nitric oxide secretion of carp head kidney leukocytes. Cells were cultured in presence of 2 or $20 \mathrm{mmol} \mathrm{l}^{-1} \mathrm{Cr}$ and stimulated with $1 \mathrm{mg} \mathrm{l}^{-1}$ pokeweed mitogen. Cells without chromium served as controls. After $4 \mathrm{~d}$, nitric oxide was determined in culture supernatant (means + SD of cultures from 6 carp). (c) Impact of chromium on production of reactive oxygen species (ROS) by carp head kidney leukocytes. Cells were incubated in presence of chromium, and their capacity to generate ROS upon phorbol myristate acetate activation was determined after 2, 4 or $6 \mathrm{~d}$ of culture (means $+\mathrm{SD}$ of cultures from 6 carp). *: Significant difference at $p<0.05$

creased concentrations of carp serum to the culture medium. Although 20 or $200 \mu \mathrm{M}$ alpha tocopherol had no effect on chromate cytotoxicity (data not shown), an addition of carp serum significantly reduced the chromate associated cell death (Fig. 1b), and a serum concentration of $10 \%$ was partially protective (Fig. 1b).

\section{Effect on neutrophils}

When head kidney-derived leukocytes were analysed by means of flow cytometry, neutrophils showed most prominent changes in their FSC/SSC profiles in the presence of hexavalent chromium. In this cell population, a shift towards increased FSC characteristics was already noticed after $2 \mathrm{~d}$ incubation at $2 \mu \mathrm{mol}$ (not shown) or
$20 \mu \mathrm{mol} \mathrm{l^{-1 }}$ chromate (Fig. 2a). After $4 \mathrm{~d}$ exposure, phagocyte functions, measured as nitric oxide secretion and ROS (reactive oxygen species) production, were significantly suppressed (Fig. 2b,c). A reduction in neutrophil numbers relative to unexposed cultures occurred after $4 \mathrm{~d}$ incubation in the presence of $200 \mu \mathrm{mol} \mathrm{l}^{-1}$ chromate (Fig. 3), while chromium-induced reduction of lymphocyte numbers occurred only after $6 \mathrm{~d}$ exposure (Fig. 3).

\section{Modulation of peripheral blood- leukocyte responses}

To determine whether $\mathrm{Cr}$ challenge induced a modulation of functions in peripheral-blood-derived lymphocytes, mitogeninduced cell proliferation was monitored. Leukocytes responded to stimulation with PWM in the presence of 20 or $200 \mu \mathrm{mol} \mathrm{l}^{-1}$ hexavalent chromium with the formation of significantly lower numbers of activated cells (blasts) relative to controls without the addition of chromium. The number of lymphocytes, however, was not affected after 2 or $4 \mathrm{~d}$ incubation (Fig. 4).

\section{DISCUSSION}

In vitro exposure of carp leukocytes to hexavalent chromium-induced cytotoxicity, decreased lymphocyte proliferation and phagocyte functions at doses between 2 and $200 \mu \mathrm{mol} \mathrm{Cr}{ }^{-1}$. This included production of reactive oxygen reagents and secretion of nitric oxide by granulocytes. Various studies have reported alterations of immune processes in experimental animals upon chromium administration (O'Neill 1981, Glaser et al. 1985, Kangarot et al. 1999, Arunkumar et al. 2000). Chromium affected the distribution of leukocytes (Glaser et al. 1985, Arunkumar et al. 2000), macrophage functions (Tian \& Lawrence 1996), and mitogen-induced proliferation of T- and B-lymphocytes (Snyder \& Valle 1991, Wang et al. 1996). In cell culture experiments, hexavalent chromium suppressed lymphocyte proliferation and immunoglobulin production (Borella et al. 1990). According to the uptake-reduction model of chromium, $\mathrm{Cr}(\mathrm{VI})$ as the chromate anion under physiological conditions readily crosses the cell membrane through the sulphate channel (Wiegand et al. 1988), while $\mathrm{Cr}(\mathrm{III})$ enters the cell via diffusion and phagocytosis at 


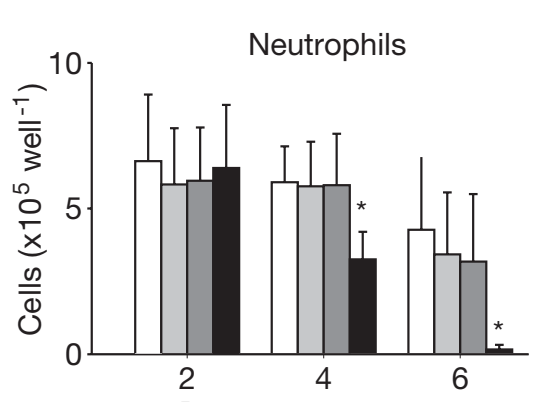

Days post-exposure

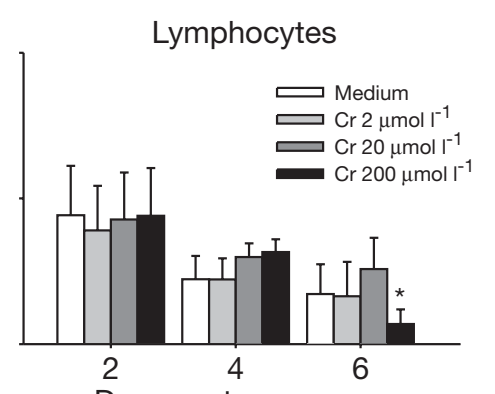

Days post-exposure

Fig. 3. Cyprinus carpio. Impact of chromium on viability of head kidneyderived carp leukocyte subsets. Cells were incubated in RPMI medium supplemented with $3 \%$ carp serum (culture medium) in presence of chromium at $25^{\circ} \mathrm{C}_{i}$ cultures without chromium served as controls. After 2,4 and 6 d incubation, cell numbers were determined by means of flow cytometry. Cell populations were identified according to their specific forward- and side-scatter characteristics (Verburg-van Kemenade et al. 1994, Scharsack et al. 2003). Shown are mean + SD of cultures from 9 individual carp. *: Significant difference at $\mathrm{p}<0.05$

a much lower rate (ATSDR 2000). This results in a much lower toxicity of trivalent chromium compared to the hexavalent state.

In our experiments, chromium-induced cytotoxicity to carp leukocytes was seen after pulsing cells with chromate for $18 \mathrm{~h}$ or after incubation in the presence of chromate for several days, which indicates a fast uptake of cytotoxic $\mathrm{Cr}(\mathrm{VI})$.

Within the cell, hexavalent chromium is rapidly reduced to lower oxidation states by various intracellular components. Intracellular reductants include ascorbate, glutathione and amino acids (Goodgame \& Joy 1987, Stearns \& Wetterhahn 1994, Pattison et al. 2000). The ultimate step of this metabolic pathway yields $\mathrm{Cr}(\mathrm{III})$ inserted within the cell nucleus, where it crosslinks DNA to proteins or glutathione (Miller et al. 1991, Voitkun et al. 1998). These Cr(III)-dependent reactions were responsible for the induction of replication blockage by $\mathrm{Cr}(\mathrm{VI})$ (Zhitkovich et al. 2002), and most likely for the reduction of lymphocyte proliferation rates to mitogens, as reported for mammalian (Wang et al. 1996) or carp cells (present communication). In our cultures, the number of activated carp leukocytes was reduced in the presence of 2 and $20 \mu \mathrm{mol} \mathrm{Cr}(\mathrm{VI}) \mathrm{l}^{-1}$ in a dose-dependent manner, while the number of nonactivated lymphocytes remained unchanged up to a

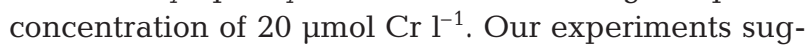
gest that in the presence of serum an extracellular pathway of chromate reduction to the less toxic trivalent state may occur. This could explain the partial protection of carp leukocytes from chromium-induced cell death in the presence of high serum supplements.

A key role in $\mathrm{Cr}(\mathrm{VI})$-induced cytotoxicity is the oxidative deterioration of biological macromolecules during the reduction of $\mathrm{Cr}(\mathrm{VI})$ to $\mathrm{Cr}(\mathrm{V}), \mathrm{Cr}(\mathrm{IV})$ and $\mathrm{Cr}(\mathrm{III})$ by

intracellular ascorbates and thiols (Stohs et al. 2000, Zhitkovich et al. 2002). The relative amount of intermediate $\mathrm{Cr}$ forms (and damage induced by them) seems to depend on the ratio of reducing agents to $\mathrm{Cr}(\mathrm{VI})$ (Lay \& Levina 1998). In carp, head kidney neutrophils were highly susceptible to Cr-induced cytotoxicity. These cells contained elevated amounts of thiols compared to peripheral blood leukocytes (Saeij et al. 2003), which makes them highly vulnerable to Cr-related oxidative damage. Carp neutrophils responded to $\mathrm{Cr}$ challenge with changes in cell shape together with reduced nitric oxide or reactive oxygen production. Neutrophil activation with secretion of nitric oxide was reported in the context of parasite infection of carp (Saeij et al. 2002, Scharsack et al. 2003). In murine macrophages, Cr suppressed the activity of the NO-producing enzyme-inducible NO synthase (Tian \& Lawrence 1996), and in rats, the number of macrophages decreased upon Cr exposure (Glaser et al. 1985). These observations suggest that chromium exposure may interfere with defence mechanisms against pathogens.

In fishes, contaminating chromium from the environment is accumulated in kidney, liver and spleen in a dose-dependent manner (Khangarot et al. 1999), i.e. in organs that are important for antigen-trapping (Zapata \& Cooper 1990). Earlier work (Strick et al. 1975, Kangarot et al. 1999) reported an increased susceptibility of chromium-exposed fishes to bacterial pathogens such as Aeromonas hydrophila. Overall, published in vivo work and our in vitro experiments give a good indication that hexavalent chromium can modulate various cell-mediated immune responses in fishes and interfere with host resistance to pathogens.

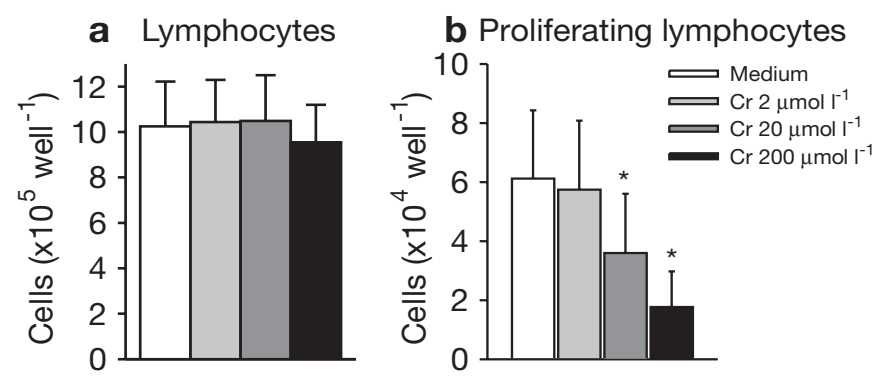

Fig. 4. Cyprinus carpio. Impact of chromium on mitogeninduced proliferation of carp peripheral blood. Cells were stimulated with $1 \mathrm{mg} \mathrm{l}^{-1}$ pokeweed mitogen and incubated in presence of chromium at $25^{\circ} \mathrm{C}$; cultures without chromium served as controls. After $4 \mathrm{~d}$ incubation, total numbers of viable small lymphocytes (a) and activated lymphocytes (b) were determined by means of flow cytometry. Shown are means + SD of cultures form 6 carp. *: Significant difference at $\mathrm{p}<0.05$ 
Acknowledgements. This study was financially supported by a grant from the Volkswagen Foundation.

\section{LITERATURE CITED}

Alpoim MC, Geraldes CF, Oliveira CR, Lima MC (1995) Molecular mechanisms of chromium toxicity: oxidation of haemoglobin. Biochem Soc Trans 23:241S

Arfstein DP, Aylward LL, Karch NJ (1998) Chromium. In: Zelikoff JT, Thomas PT (eds) Immunotoxicology of environmental and occupational metals. Taylor \& Francis, London, p 63-92

Arunkumar RI, Rajasekaran P, Michael RD (2000) Differential effects of chromium compounds on the immune response of the African mouth breeder Oreochromis mossambicus (Peters). Fish Shellfish Immunol 10:667-676

ATSDR (Agency for Toxic Substance and Disease Registry) (2000) Toxicological profile for chromium. ATSDR PB93-182434, ATSDR, Atlanta, GA

Borella P, Bargellini A (1993) Effects of trace elements on immune system: results in cultured human lymphocytes. J Trace Elem Electrolytes Health Dis 7:231-233

Borella P, Manni S, Giardino A (1990) Cadmium, nickel, chromium, and lead accumulate in human lymphocytes and interfere with PHA-induced proliferation. J Trace Elem Electrolytes Health Dis 4:87-97

Glaser U, Hochrainer D, Kloppel D, Kuhmen H (1985) Low level chromium(VI) inhalation effects on alveolar macrophages and immune functions in Wistar rats. Arch Toxicol 57:250-256

Goodgame DML, Joy M (1987) EPR study of the $\mathrm{Cr}(\mathrm{V})$ and radical species produced in the reduction of $\mathrm{Cr}(\mathrm{VI})$ by ascorbate. Inorg Chim Acta 135:115-118

Goyer RA (1991) Toxic effects of metals. In: Amdur MO, Doull J, Klaassen CD (eds) Casaret and Doulls toxicology: the basic science of poisons, 4th edn. McGraw-Hill, New York, p 623-680

Green LC, Wagner DA, Glogowski J, Skipper PL, Wishnok JS, Tannenbaum S (1982) Analysis of nitrate, nitrite, and $\left({ }^{15} \mathrm{~N}\right)$ nitrate in biological fluids. Anal Biochem 126:131-138

Khangarot BS, Rathore RS, Tripathi DM (1999) Effects of chromium on humoral and cell-mediated immune responses and host resistance to disease in a freshwater catfish, Saccobranchus fossilis (Bloch). Ecotoxicol Environ Saf 43:11-20

Langård S (1982) Absorption, transport, and excretion of chromium in man and animals. In: Langård S (ed) Topics in environmental health, Vol 5. Biological and environmental aspects of chromium. Elsevier, Amsterdam, p 5-44

Lay P, Levina A (1998) Activation of molecular oxygen during the reactions of chromium(VI/V/IV) with biological reductants: implications of chromium-induced genotoxicities. J Am Chem Soc 120:6704-6714

Miller NW, McKinney EC (1994) In vitro culture of fish leukocytes. In: Hochachka PW, Mommsen TP (eds) Biochemistry and molecular biology of fishes. 3. Elsevier, Amsterdam, p 341-353

Miller CA III, Cohen MD, Costa M (1991) Complexing of actin and other nuclear proteins to DNA by cis-diaminendichloroplatinum(II) and chromium compounds. Carcinogenesis 12:269-276

Nishio A, Uyeki EM (1985) Inhibition of DNA synthesis by chromium compounds. J Toxic Environ Health 15:237-44

O'Neill JG (1981) The humoral response of Salmo trutta L. and Cyprinus carpio L. exposed to heavy metals. J Fish Biol 19:297-306
Pattison DI, Lay PA, Davies MJ (2000) EPR studies of chromium(V) intermediates generated via reduction of chromium (VI) by DOPA and related catecholamines: potential roles of oxidised amino acids in chromiuminduced cancers. Inorg Chem 36:2729-2739

Pechhold K, Pohl T, Kabelitz D (1994) Rapid quantification of lymphocyte subsets in heterogeneous cell populations by flow cytometry. Cytometry 16:152-159

Polak L (1983) Immunology of chromium. In Burrows D (ed) Chromium: metabolism and toxicity. CRC Press, Boca Raton, FL, p 51-136

Saeij JPJ, van Muiswinkel WB, Groeneveld A, Wiegertjes GF (2002) Immune modulation by fish kinetoplastid parasites: a role for nitric oxide. Parasitology 124:77-86

Saeij JPJ, van Muiswinkel WB, van de Meent M, Amaral C, Wiegertjes GF (2003) Different capacities of carp leukocytes to encounter nitric oxide-mediated stress: a role for the intracellular reduced glutathione pool. Dev Comp Immunol 27:555-568

Scharsack JP, Steinhagen D, Kleczka C, Schmidt JO, Körting W, Michael RD, Leibold W, Schuberth HJ (2003) The haemoflagellate Trypanoplasma borreli induces the production of nitric oxide, which is associated with modulation of carp (Cyprinus carpio L.) leukocyte functions. Fish Shellfish Immunol 14:207-222

Schuberth HJ, Anders I, Pape U, Leibold W (1992) Onedimensional isoelectric focusing and immunoblotting of equine major histocompatibility complex class I antigens. Anim Genet 23:87-95

Snyder CA, Valle CD (1991) Immune function assays as indicators of chromate exposure. Environ Health Perspect 92: 83-86

Stearns DM, Wetterhahn KE (1994) Reaction of chromium(VI) with ascorbate produces chromium(V), chromium(IV), and carbon-based radicals. Chem Res Toxicol 7:219-230

Stohs SJ, Bagchi D, Hassoun E, Baghi M (2000) Oxidative mechanism in the toxicity of chromium and cadmium ions. J Environ Pathol Toxicol Oncol 19:201-213

Strik JJTWA, de Longh HH, van Rijn van Alkemade JWA, Wuite TP (1975) Toxicity of Chromium VI in fish, with special reference to organ weights, liver and plasma enzyme activities, blood parameters and histological alterations. In: Koeman JH, Strik JJTWA (eds) Sublethal effects of toxic chemicals on aquatic animals. Elsevier, New York, p 31-58

Sudhan T, Michael RD (1995) Modulation of humoral immune response by tannery effluent in Oreochromis mossambicus (Peters). Indian J Exp Biol 33:793-795

Tian L, Lawrence DA (1996) Metal-induced modulation of nitric oxide production in vitro by murine macrophages: lead nickel, and cobalt utilise different mechanisms. Toxicol Appl Pharmacol 141:540-547

Verburg-van Kemanade BM, Groeneveld A, van Rens BTTM, Rombout JHWM (1994) Characterisation of macrophages and neutrophilic granulocytes from the pronephros of carp (Cyprinus carpio). J Exp Biol 187:143-158

Vincent JB (1999) Mechanisms of chromium binding action: low-molecular-weight chromium-binding substance. J Am Coll Nutr 18:6-12

Voitkun V, Zhitkovich A, Costa M (1998) Cr(III)-mediated crosslinks of glutathione or amino acids to the DNA phosphate backbone are mutagenic in human cells. Nucleic Acids Res 26:2024-2030

Wang JY, Tsukayama DT, Wicklund BH, Gustilo RB (1996) Inhibition of T and B proliferation by titanium, cobalt, and chromium: role for IL-2 and IL-6. J Biomed Mater Res 32: 655-661 
Wiegand HJ, Ottenwälder H, Boldt HM (1988) Recent advances in biological monitoring of hexavalent chromium compounds. Sci Total Environ 71:309-315

Wiegertjes GF, Groeneveld A, van Muiswinkel WB (1995) Genetic variation in susceptibility to Trypanoplasma borreli infection in common carp (Cyprinus carpio L.). Vet Immunol Immunopathol 47:153-161

Ye J, Wang S, Leonard SS, Sun Y, Butterworth L and 7 others (1999) Role of reactive oxygen species and p53 in

Editorial responsibility: Thomas Braunbeck, Heidelberg, Germany chromium (VI)-induced apoptosis. J Biol Chem 274: 34975-34980

Zapata AG, Cooper EL (1990) The immune system: comparative histophysiology. Wiley, Chichester

Zhitkovich A, Quievryn G, Messer J, Motylevich Z (2002) Reductive activation with cysteine represents a chromium(III)-dependent pathway in the induction of genotoxicity by carcinogenic chromium(VI). Environ Health Perspect 110 (Suppl 5):729-731

Submitted: March 18, 2004; Accepted: June 15, 2004 Proofs received from author(s): October 22, 2004 